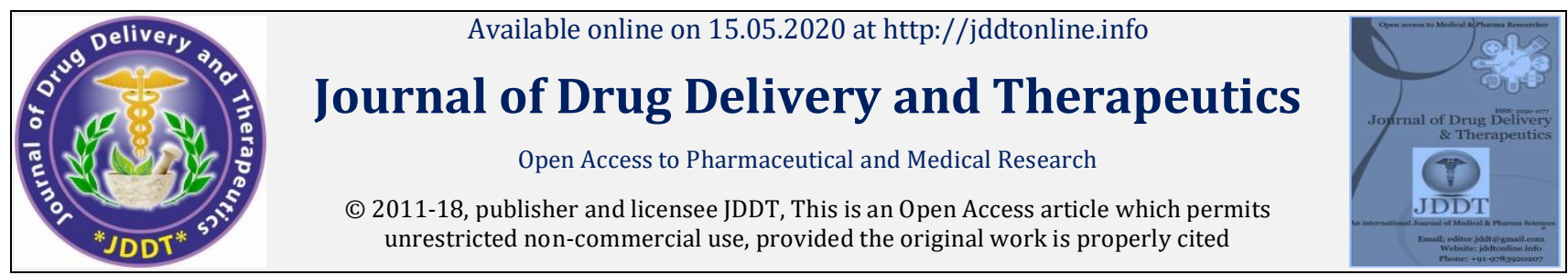

Open 1 Access

Review Article

\title{
Management of Hypertension with Conventional and Herbals Drugs
}

\author{
Marjina $^{1}$, Amandeep Singh ${ }^{1,3}$, Amit Sharma ${ }^{2}$, Raj Kumar Narang1 ${ }^{1}$ Gurmeet Singh ${ }^{*}$ \\ ${ }^{1}$ Department of Pharmaceutics, ISF College of Pharmacy, Moga-142001, Punjab, India \\ 2Department of Pharmacy practice, ISF College of Pharmacy, Moga-142001, Punjab, India \\ ${ }^{3}$ Department of Pharmaceutical Sciences and Technology, Maharaja Ranjit Singh Punjab Technical University, Bathinda- 151001, Punjab, India
}

\begin{abstract}
In this article, we have discussed about Types (primary, secondary, isolated, white coat, malignant, resistant and pulmonary hypertension), classification, adverse drug reactions of antihypertensive drugs (beta-blocker induce psoriasis and calcium channel blocker cause peripheral oedema. ACE inhibitor produce ankle oedema and thiazide diuretics causes hypenatremia and also hyperglycaemia. These are some of the serious adverse drug reactions associated with patients who are being treated with these drugs), measurement, management, diagnosis and associated diseases (e.g. diabetes mellitus, heart disease, cerebrovascular disease) lastly concluded about the herbal approach for management of hypertension
\end{abstract}

Keywords: Hypertension, conventional drugs, Herbal drugs

Article Info: Received 11 March 2020; Review Completed 22 April 2020; Accepted 29 April 2020; Available online 15 May 2020

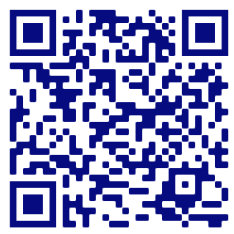

Code: 142001.

\section{Cite this article as:}

Marjina, Singh A, Sharma A, Narang RK, Singh G, Management of Hypertension with Conventional and Herbals Drugs, Journal of Drug Delivery and Therapeutics. 2020; 10(3):280-287 http://dx.doi.org/10.22270/jddt.v10i3.3998

\section{*Address for Correspondence:}

Mr Gurmeet Singh, Assistant Professor, Department of Pharmaceutics, ISF College of Pharmacy, Moga, Punjab, India Postal

\section{INTRODUCTION}

Persistent elevation in blood pressure is known as hypertension. In hypertension, systolic blood pressure (SBP) is greater than $140 \mathrm{mmHg}$ or diastolic blood pressure (DBP) is greater than $90 \mathrm{mmHg} .{ }^{14}$

Table 1: Categories/stages of hypertension: (14)

\begin{tabular}{|c|c|c|}
\hline Category & SBP & DBP \\
\hline Normal & $<120$ & $<80$ \\
\hline Pre-hypertension & $120-139$ & $80-89$ \\
\hline Stage-1 & $140-159$ & $90-99$ \\
\hline Stage-2 & $>160$ & $>100$ \\
\hline
\end{tabular}

Blood pressure $(\mathrm{BP})=$ cardiac output $(\mathrm{CO}) \times$ peripheral vascular resistance
Cardiac output (CO) = heart rate (H.R.) $\times$ stroke volume (SV)

Heart rate: number of beats per minute (72).

Stroke volume: The amount of blood pumped in 1 heart beat $(60 \mathrm{ml})$.

\subsection{Epidemiology}

Hypertension is public health problem in both developing and developed countries and affecting about 20\% adult population shown in figure 1 . Worldwide, 7.5 million premature deaths (about $13.5 \%$ of the global total) were due to hypertension. About $55 \%$ of stroke and $48 \%$ of ischaemic heart diseases worldwide attributable to high blood pressure. Prevalence of hypertension in India is about $27 \%$ in men and $24 \%$ in women. According to statistics cases of hypertension increased 10 times in last 4 decades in rural India and almost 30 times in urban India 1. 


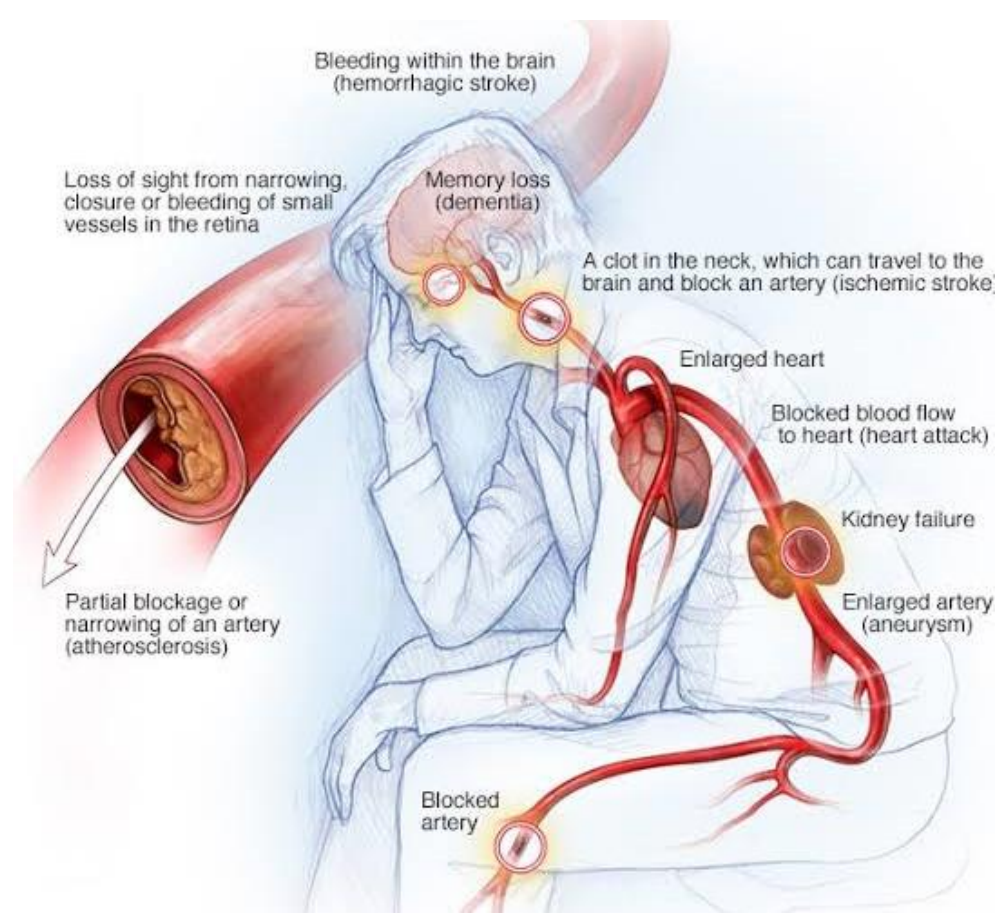

Fig. 1 Negative impact of hypertension

\subsection{Symptoms}

Hypertension has no sign and symptoms. Therefore, it is also called as "silent killer". A small amount of people may experience symptoms such as:

- $\quad$ Severe Headache

- Vomiting

- Nosebleeds

- Fatigue

- $\quad$ Chest pain

- $\quad$ Blurred vision

But, these symptoms usually do not occur until blood pressure level reaches to life threatening stage 2 .

\subsection{Causes of Hypertension}

- Hereditary

- Obesity

- High sodium intake

- $\quad$ Psychological stress

- $\quad$ stress

Other factors also play a role:

- $\quad$ Excessive alcohol drinking

- Smoking

- $\quad$ Physical inactivity ${ }^{3}$.

\section{TYPES OF HYPERTENSION}

2.1 Primary hypertension/essential hypertension (95 to 96\%): it has no clear cause. But, frequent headache and tiredness is common.

2.2 Secondary hypertension (4 to $5 \%$ ): in secondary hypertension cause can be found and it includes:
- Hormonal abnormalities

- Too much salt in the diet

- Alcohol consumption

- Drugs can also cause secondary hypertension

Example: over the counter drug (OTC), ibuprofen, Pseudoephedrine.

If the cause is found, hypertension (HTN) can often be controlled 4 .

\section{OTHER TYPES OF HYPERTENSION}

3.1 Isolated systolic hypertension: in this, systolic blood pressure tends to rise above 140 and diastolic blood pressure tends to fall and most common in people over the age 65 .

3.2 White coat hypertension: this term is used to denote individuals who have normal BP outside doctor's office but, high $\mathrm{BP}$ in the medical environment therefore, the patients with this type of hypertension feel extremely stressed when they visit doctor's office.

3.3 Malignant hypertension: occur only in 1\% of people with hypertension and in this DBP goes over 130, treated only in hospital.

3.4 Resistant hypertension: if three different types of medications are prescribed by the doctor but, blood pressure is still too high. Then it is called resistant hypertension 5 .

3.5 Pulmonary hypertension: pulmonary hypertension means high blood pressure in the arteries going to lung. In healthy individuals, the BP in these arteries is much lower than in the rest of the body.

Pulmonary arterial BP is about $25 / 10 \mathrm{mmHg}$ in healthy individuals. If this pressure exceeds $40 / 20 \mathrm{mmHg}$ it means pulmonary hypertension is present 6 . 


\section{CLASSIFICATION OF ANTI-HYPERTENSIVE DRUGS}

\subsection{Diuretics}

Diuretics such as hydrochlorthiazide lower BP by increasing sodium and water excretion or urination. This cause a decrease in cardiac output and peripheral resistance and ultimately blood pressure decreases. Examples are Bumetanide, Furosemide, Hydrochlorthiazide, Spironolactone, Triamterene 14.

\subsection{Beta-blockers}

The $\beta$-blockers reduce blood pressure by decreasing cardiac output and also inhibit the release of rennin from the kidneys, thus decreasing the formation of angiotensin- 2 and the secretion of aldosterone therefore volume of blood decreases which leads to decrease in BP. Examples are Atenolol, Propranolol, Labetolol, Timolol 14.

\subsection{ACE inhibitors}

These drug blocks the ACE that convert angiotensin-1 into angiotensin-2. Thus, ACE inhibitors decrease angiotensin-2 level so, reduce constriction and also secretion of aldosterone that control the level of sodium and water ions. Hence, B.P. decreases. Examples are Captopril, Enalapril, Lisinopril, Quinapril, Ramipril 14.

\subsection{Angiotensin2-receptor antagonist (ARB)}

Angiotensin receptor blocker alternative to the ACE inhibitors. These drugs blocks the AT1 receptors, result in vasodilatation and also block aldosterone secretion. Examples are Candesartan, Irbesartan, Losartan, Telmisartan, Valsartan 14.

\subsection{Renin inhibitors}

Aliskiren directly inhibit rennin and thus, acts earlier in the rennin angiotensin aldosterone system than ACE inhibitors or ARBs. It decreass blood pressure about as effectively as ARBs, ACE inhibitors and thiazides. For example Aliskiren. But, aliskiren cause diarrhea at higher doses 14 .

\subsection{Calcium channel blockers}

Calcium is responsible for contraction and the calcium channel antagonist block the inward movement of calcium by binding to L-type calcium channels in the heart, these cause vascular smooth muscles to relax or channel blockers lower B.P by reducing myocardial contractility. For example, Amlodipinem, Diltiazem, Felodipine, Nicardipine, Nifedipine, Verapamil ${ }^{14}$.

\subsection{Alpha- blockers}

Alpha blockers block the $\alpha 1$ receptor. They decrease peripheral vascular resistance and lower arterial blood pressure by causing relaxation of both arterial and venous smooth muscles because these receptors are present on vascular smooth muscle. For example Prazosin, Doxazosin 14.

\subsection{Other}

Sodium nitroprusside: nitroprusside is administered intravenously and cause prompt vasodilation. It is capable of reducing $\mathrm{BP}$ in all the patients.but, nitroprusside is metabolized quickly and requires continuous infusion for the maintainance of its hypotensive action. For example Hydralazine(vasodilator) ${ }^{14}$.

Table 2: Commonly used antihypertensive drugs: ${ }^{7}$.

\begin{tabular}{|c|c|c|c|c|}
\hline S.NO. & CLASS & GENERIC NAME & DOSE(mg) & BRAND NAME \\
\hline 1. & Diuretics & Hydrochlorthiazide & $12.5-50$ & Hydrex \\
& & Indapamide & $1.25-5$ & Natrilex \\
& & furosemide & $200-400$ & Blockium \\
\hline 2. & Beta-blocker & Atenolol & $25-100$ & Betaloc \\
\hline 3. & Calcium antagonist & Metaprolol & $50-200$ & $120-480$ \\
& & Verapamil & $90-240$ & Tarka isoptin retard \\
\hline 4. & ACE inhibitors & Diltiazem & $50-150$ & Capozide \\
& & Captopril & $2.5-40$ & Ezapril \\
& & Enalapril & $10-40$ & Festril \\
\hline 5. & ARB & Lisinopril & $25-100$ & Cortzar \\
& & Losartan & $80-320$ & Atacand \\
\hline 6. & Alpha-blocker & Valsartan & $4-32$ & Minipress \\
& & Candesartan & $1-16$ & Cardura \\
\hline 7. & Centrally acting & Prazosin & $1-16$ & Aldomet \\
& drugs & Doxazosin & $500-2000$ & Catapres \\
\hline
\end{tabular}

\section{ADVERSE EFFECTS OF ANTI HYPERTENSIVE DRUGS}

\subsection{Hypokalemia}

Diuretics cause hypokalemia and it is treated by rational medication combination. Low dose thiazide combined with ACE or ARBs to maintain the potassium concentration sufficiently.

\subsection{Hyponatremia}

One of the most common problems with thiazide diuretics is hyponatremia. Those who develop hyponatremia should be changed to other class of drugs. If still diuretics are required a low dose of long acting loop diuretics (e.g. torsemide 2.5$5 \mathrm{mg}$ daily) is effective. 


\subsection{Edema}

Antihypertensive medication induced edema is more common. Women may be particularly susceptible to calcium channel blocker induced edema. But, peripheral edema can be minimized by decreasing the dose.

\subsection{Erectile dysfunction}

It affects about $30 \%$ of men with hypertension. Both hypertension and erectile dysfunction are disorders of endothelial dysfunction. Preliminary evidence suggests that combination of phosphodiesterase type-5 inhibitors (PDE5) and alpha-blockers improve erectile dysfunction ${ }^{8}$.

\subsection{Psoriasis}

The use of beta-blocker may result in psoriasis and if we substitute any other beta-blocker it may further cause skin lesions. If psoriasis is present only in localized area then, emollients can be helpful.

\subsection{Hyperglycaemia}

Hyperglycaemia is more common and severe adverse effect is seen with thiazide diuretics than other class of antihypertensive drugs. Patient with diuretic induced hyperglycaemia are often considered as having type-2 diabetes and are prescribed with oral anti-diabetic agent ${ }^{9}$.

\section{B.P. MEASUREMENT}

\subsection{Sphygmomanometer}

The sphygmomanometer was invented by Samuel Siegfried Karl Ritter Von Basch in the year 1881. Sphygmomanometer self-measurement of blood pressure device.

6.2 Points to be considered during the measurement of B.P. ${ }^{10}$.

\subsubsection{Posture of patient}

Allow the patient to be seated for few minutes before the measurement of blood pressure. B.P. should be measured when the patient in a relaxed state, the arm at the level of heart and the legs are not crossed.

\subsubsection{B.P. device}

The device should be validated.

\subsubsection{Cuff size}

The cough with bladder whose length is at least $80 \%$ of the arm circumference is preferable.

\subsubsection{Number of measurements}

At least two readings should be taken at each visit with an interval of at least $1 \mathrm{~min}$. this will avoid the calculation error involved in averaging the two measurements. Due to variability of B.P. measurements the diagnosis of hypertension should be made only after multiple readings.

Table 3:

\begin{tabular}{|l|l|l|}
\hline S.NO. & Measurement error & Effect on B.P. \\
\hline $\mathbf{1 .}$ & Back is not supported & Diastolic blood pressure increased by $6 \mathrm{mmHg}$ \\
\hline $\mathbf{2 .}$ & Legs are crossed & Systolic B.P. increased by $2-8 \mathrm{mmHg}$ \\
\hline $\mathbf{3 .}$ & Arm is not at the level of heart & Increase B.P. by $10-12 \mathrm{mmHg}$ \\
\hline
\end{tabular}

\section{MANAGEMENT OF HYPERTENSION 11.}

Non pharmacological management plays an important role for the improvement of overall cardiovascular diseases. It include:

7.1 Weight reduction: Dietary interventions to lower body weight also recommended for people with hypertension. Weight reducing diet reduces about $4.5 / 3.2 \mathrm{mmHg}$ blood pressure.

7.2 Sodium intake: Reduce sodium intake sufficiently reduces B.P. in adults. A recent study has shown that reduction of sodium intake from $11.6 \mathrm{~g}$ of salt to $3.8 \mathrm{~g}$ of salt decrease the B.P. in asian people.

7.3 Alcohol consumption: Alcohol consumption increases B.P. reducing alcohol intake reduce B.P. by $3.3 / 2 \mathrm{mmHg}$. People who drink are advised to limit the consumption of alcohol.

7.4 Regular physical activity: Increased physical activity has been shown to reduce blood pressure. Aerobic exercise of at least $150 \mathrm{~min}$. per week is beneficial.

7.5 Healthy eating: A diet rich in fruits, vegetables, low fat dairy products can lower B.P. DASH (dietary approaches to stop hypertension) diet significantly lower the B.P. and it include, Grains, Vegetables, Fruits, Low fat dairy foods, Nut, seeds, beans.
7.6 Cessation of smoking: Smoking cessation is important in reducing global cardiovascular risk.

7.7 Dietary potassium intake: Increase dietary potassium intake reduces B.P. in adults without adverse effect on blood lipid concentration. Dietary potassium can reduce B.P. by $3.49 / 1.96 \mathrm{mmHg}$ and also lower the risk of stroke by $25 \%$ this can be achieved by eating fruits, vegetables, nuts and legumes.

\section{ASSOCIATED DISEASES WITH HYPERTENSION}

\subsection{Diabetes mellitus}

Patient with diabetes mellitus should be initiated on drug therapy when the SBP is greater than $140 \mathrm{mmHg}$. ACE inhibitors are used initially than calcium channel blockers and diuretics used as add on therapy.

\subsection{Heart disease}

Beta-blockers used in patient with hypertension and a recent myocardial infarction. In case of angina, beta-blockers and calcium channel blockers are prefer but, in patient with heart failure and hypertension thiazide diuretics are more preferable.

\subsection{Cerebrovascular disease}

Initiation of drug treatment should be considered with grade 1 hypertension in patient with stroke history. Do not administer antihypertensive drugs in first 72 hours of ischemic stroke 12 


\section{DIAGNOSIS OF HYPERTENSION:}

9.1 Measure B.P. in both the arms for the diagnosis of hypertension

9.1.1 Repeat the measurements, if the difference in readings between arms is more than $15 \mathrm{mmHg}$.

9.1.2 Measure subsequent B.P. in the arm if the difference between the arms more than $15 \mathrm{mmHg}$ on the second measurement.

9.2 When B.P. measurement is inside the clinic $140 / 90 \mathrm{mmHg}$ or higher

9.2.1 During the consultation take second measurement.
9.2.2 Take third measurement if second is different from first

9.3 Ambulatory blood pressure monitoring (ABPM) - if clinic blood pressure is between $140 / 90$ and $180 / 120 \mathrm{mmHg}$ to confirm the diagnosis of hypertension.

9.4 If ABPM is unsuitable for the person offer home blood pressure monitoring (HBPM) for the diagnosis of hypertension.

9.5 When using ABPM ensure that at least 2 measurements taken per hour during the person's waking hour (e.g. between 8.00 and 22.00). When using HBPM ensure that for each blood pressure recording, 2 consecutive measurements are taken ${ }^{13}$.

\begin{tabular}{|l|l|}
\hline \multicolumn{1}{|c|}{ Patient presentation } & \multicolumn{1}{|c|}{ Patient presents with uncontrolled BP (>140/90) } \\
\hline Check clinic blood pressure & $\begin{array}{l}\text { Controlled clinic blood pressure measurement: } \\
\text { Take a first measurement. } \\
\text { Take a second measurement, if BP is high. } \\
\text { If the last measurement is different from the first, take a third } \\
\text { measurement. } \\
\text { The last two measurements recorded as a clinic BP. }\end{array}$ \\
\hline Rule out white coat hypertension & $\begin{array}{l}\text { Refer for ambulatory BP monitoring, if blood pressure is } \\
\text { uncontrolled. }\end{array}$ \\
\hline Rule out non-adherence to medication & $\begin{array}{l}\text { If BP is uncontrolled on ABPM consider: } \\
\text { Urine analysis } \\
\text { Directly observed dosing }\end{array}$ \\
\hline Diagnosis & $\begin{array}{l}\text { Diagnosis of resistant hypertension can be made if BP is } \\
\text { uncontrolled. }\end{array}$ \\
\hline
\end{tabular}

10. NOVEL DRUG DELIVERY SYSTEM FOR HYPERTENSION

\begin{tabular}{|c|c|c|c|}
\hline S. N. & Drug & $\begin{array}{l}\text { Delivery system/formulation } \\
\text { approaches }\end{array}$ & Applications \\
\hline 1. & Perindopril & $\begin{array}{l}\text { Mucosal administration route ODT: } \\
\text { orodispersible tablets perindopril arginine }\end{array}$ & $\begin{array}{l}\text { Treatment of hypertension/heart } \\
\text { failure }^{15} \text {. }\end{array}$ \\
\hline 2. & Nitrendipine & Sublingual mucosal route & $\begin{array}{l}\text { Effectively reduce B.P during first } 45 \\
\min ^{15} \text {. }\end{array}$ \\
\hline 3. & Amlodipine & Transmucosal administration & $\begin{array}{l}\text { Effective in coronary heart disease and } \\
\text { hypertension } 15 \text {. }\end{array}$ \\
\hline 4. & Metaprolol & $\begin{array}{l}\text { Rectal administration of metaprolol } \\
\text { tartrate }\end{array}$ & $\begin{array}{l}\text { Reduce B.P. significantly faster } \\
\text { without severe side-effects }{ }^{15} \text {. }\end{array}$ \\
\hline 5. & Propranolol & $\begin{array}{l}\text { Rectal administration and } \\
\text { Sublingual administation }\end{array}$ & Sustain release of drug15. \\
\hline 6. & Carvedilol & $\begin{array}{l}\text { Solid lipid nanoparticles(SLN) } \\
\text { And nanosuspensions }\end{array}$ & $\begin{array}{l}\text { Enhance bioavailability and protecting } \\
\text { it from acidic environment }{ }^{16} \text {. }\end{array}$ \\
\hline 7. & Candesartan cilexitil & $\begin{array}{l}\text { Dendrimers and } \\
\text { Nanosuspensions }\end{array}$ & Improved water solubility ${ }^{16}$ \\
\hline 8. & Nifedipine & $\begin{array}{l}\text { Polymeric nanoparticles and } \\
\text { Dendrimers }\end{array}$ & Increase dissolution rate ${ }^{16}$ \\
\hline 9. & Felodipine & $\begin{array}{l}\text { Nanosuspensions/ } \\
\text { Polymeric nanoparticles }\end{array}$ & Control the release of drug16. \\
\hline 10. & Valsartan & $\begin{array}{l}\text { Proliposomes and self non -emulsifying } \\
\text { drug delivery system }\end{array}$ & $\begin{array}{l}\text { *Bypass first pass metabolism } \\
\text { *Prolong release of drug16. }\end{array}$ \\
\hline 11. & Nebivolol & Polymeric nanoparticles & Prolonged drug release 16. \\
\hline 12. & Isradipine & Transdermal penetration of drug & Management of hypertension ${ }^{17}$. \\
\hline 13. & Olmesartan & $\begin{array}{l}\text { Nano-invasomes formulation/Transdermal } \\
\text { delivery system(TDDS) }\end{array}$ & Increase bioavailability ${ }^{17}$ \\
\hline 14. & Bosentan & $\begin{array}{l}\text { Nanoparticles endothelin receptor } \\
\text { antagonist }\end{array}$ & Effective in pulmonary hypertension ${ }^{18}$. \\
\hline 15. & Aliskiren & $\begin{array}{l}\text { Poly(D,L-lactide)(PLA) } \\
\text { Oral gavage }\end{array}$ & Prevent stroke by lowering high B.P18. \\
\hline 16. & Lacidipine & Niosomes & Helps to relax blood vessels ${ }^{18}$. \\
\hline
\end{tabular}




\begin{tabular}{|c|c|c|c|}
\hline 17. & Captopril & Chitosan polymer/oral route & Improve survival after a heart attack \\
\hline 18. & Sildenafil & Endotracheal administration & Treat pulmonary hypertension 18. \\
\hline 19. & Tacrolimus(TAC) & $\begin{array}{l}\text { Nanocompositae particles } \\
\text { Endotracheal administration }\end{array}$ & Pulmonary hypertension \\
\hline 20. & Silaenafil & $\begin{array}{l}\text { Poly (D,L-lactide-co-glycolide) } \\
\text { nanoparticles } \\
\text { Endotracheal administration }\end{array}$ & Pulmonary HTN18. \\
\hline 21. & Cerivastatin & $\begin{array}{l}\text { Liposomes } \\
\text { Endotracheal administration }\end{array}$ & Pulmonary HTN18. \\
\hline 22. & Lercanidipine & $\begin{array}{l}\text { Proliposomes/ } \\
\text { Oral dose using intragastric tube }\end{array}$ & $\begin{array}{l}\text { Immediate and long lasting ( } 24 \mathrm{~h}) \\
\text { reduction in systolic blood pressure } 19 .\end{array}$ \\
\hline 23. & $\begin{array}{l}\text { Super- oxide dismutase } \\
\text { (SOD) }\end{array}$ & Lipose encapsulation/daily injections & $\begin{array}{l}\text { Reduce mean arterial pressure (MAP) } \\
\text { by } 50 \mathrm{mmHg}^{19} \text {. }\end{array}$ \\
\hline 24. & Covera-HS;XL tablet & $\begin{array}{l}\text { Osmotic control release oral drug delivery } \\
\text { system(OROS)/ chronopharmaceuticals }\end{array}$ & $\begin{array}{l}\text { Prevent the dangerous surge of B.P in } \\
\text { the early morning } 20 .\end{array}$ \\
\hline 25. & $\begin{array}{l}\text { Verelan PM;XL release } \\
\text { capsule }\end{array}$ & $\begin{array}{l}\text { Chronotherapeutic oral drug absorption } \\
\text { system(CODAS) }\end{array}$ & $\begin{array}{l}\text { Manage hypertension in the } \\
\text { morning } 20 .\end{array}$ \\
\hline 26. & Innopran ;XL tablets & $\begin{array}{l}\text { DIFFU CAS multiparticulate bead system } \\
\text { comprised of multiple layers of drug, } \\
\text { excipients and release controlling } \\
\text { polymers }\end{array}$ & Release is $\mathrm{pH}$ independent ${ }^{20}$. \\
\hline 27. & Pulsincap & PULSINCAP rupturable system & Release is $\mathrm{pH}$ independent ${ }^{20}$. \\
\hline 28. & Procardia XL & PROCARDIA XL sutained release tablet & $\begin{array}{l}\text { Decrease the frequency of chest pain } \\
\text { attacks } 20 .\end{array}$ \\
\hline 29. & Cardizem LA; & CEFORM extended release tablet & $\begin{array}{l}\text { Production of uniformly sized and } \\
\text { shaped microsphere } 20 .\end{array}$ \\
\hline 30. & ramipril & Polymeric nanoparticles/chitosan & $\begin{array}{l}\text { Used to treat high B.P and congestive } \\
\text { heart failure (CHF) }{ }^{20} \text {. }\end{array}$ \\
\hline 31. & Nisoldipine & Solid lipid nanoparticles & Lower high blood pressure 21. \\
\hline 32. & Eplerenone (ARB) & Oral route & Treat high blood pressure ${ }^{21}$ \\
\hline 33. & $\begin{array}{l}\text { Taladafil } \\
\text { (phosphodiesterase-5- } \\
\text { inhibitor) }\end{array}$ & Oral route & Effective in pulmonary hypertension ${ }^{21}$. \\
\hline 34. & Imidapril (ACE) inhibitors & By mouth & Manage high blood pressure 21. \\
\hline 35. & $\begin{array}{l}\text { Azilsartan (angiotensin-1 } \\
\text { receptor blocker) }\end{array}$ & Orally/40mg or $80 \mathrm{mg}$ & Treat hypertension 21. \\
\hline 36. & $\begin{array}{l}\text { Macitentan (endothelin A } \\
\text { receptor blocker) }\end{array}$ & Orally/10mg & Pulmonary hypertension ${ }^{21}$. \\
\hline 37. & $\begin{array}{l}\text { Ambrisentan } \\
\text { EARB(endothelinA } \\
\text { receptor blocker) }\end{array}$ & Film coated tablet/orally & Pulmonary HTN21. \\
\hline 38. & $\begin{array}{l}\text { Monoxidine(imidazolidine } \\
\text { receptor blocker) }\end{array}$ & Oral route & $\begin{array}{l}\text { Treat mild to moderate essential } \\
\text { hypertension } 21 .\end{array}$ \\
\hline 39. & $\begin{array}{l}\text { Cicletanine (endothelila } \\
\text { nitric oxide synthase } \\
\text { coupler) }\end{array}$ & Orally & $\begin{array}{l}\text { It's a diuretic drug for the treatment of } \\
\text { hypertension }{ }^{21} \text {. }\end{array}$ \\
\hline
\end{tabular}

\section{NOVEL BRANDED DRUGS FOR THE TREATMENT OF HYPERTENSION}

\begin{tabular}{|l|l|l|l|}
\hline S. No & Drug & $\begin{array}{l}\text { Delivery system/formulation } \\
\text { approaches }\end{array}$ & Applications \\
\hline 1 & Flolan (prostacyclin derivative) & Intravenous(I.V) & $\begin{array}{l}\text { Treatment of pulmonary arterial } \\
\text { hypertension (PAH) }\end{array}$ \\
\hline 2 & Veletri (prostacyclin derivative) & I.V & Treatment of PAH $^{22}$. \\
\hline 3 & Ventavis (prostacyclin derivative) & Inhaled & Treatment of PAH ${ }^{22}$. \\
\hline 4 & $\begin{array}{l}\text { Remodulin (prostacyclin } \\
\text { derivative) }\end{array}$ & Subcutaneous (SC)/IV & Treatment of PAH \\
\hline 5 & Tyvaso (prostacyclin derivative) & Inhaled & Treatment of PAH PA. $^{22}$. \\
\hline 6 & $\begin{array}{l}\text { Tracleer (endothelin receptor } \\
\text { antagonist/ERA) }\end{array}$ & Oral & Treatment of PAH \\
\hline 7 & Letairis (ERA) & Oral & Treatment of PAH \\
\hline 8 & Revatio (PDE-5-inhibitor) & Oral & Treatment of PAH \\
\hline 9 & Adcirca (PDE-5-inhibitor) & Oral & Treatment of PAH \\
\hline
\end{tabular}




\section{NEW COMBINATION THERAPY}

\begin{tabular}{|l|l|l|l|}
\hline S. No & Drug & $\begin{array}{l}\text { Delivery system/ } \\
\text { formulation approaches }\end{array}$ & Applications \\
\hline 1 & $\begin{array}{l}\text { Sildenafil + } \\
\text { Epoprostenol }\end{array}$ & Oral /IV & Treatment of PAH $^{22}$. \\
\hline 2 & Iloprost + Bosentan & Inhaled /oral & $\begin{array}{l}\text { For the treatment of idiopathic pulmonary arterial } \\
\text { hypertension (IPAH) }\end{array}$ \\
\hline
\end{tabular}

\section{HERBAL DRUGS AS BOOM FOR THE MANAGEMENT OF HYPERTENSION:}

- The use of herbal medicines throughout the world exceeds as compare to conventional drugs by two to three times.

- It is the oldest form of health care for the prevention and treatment of illness.

- Herbal drugs are phytochemical compounds used for the treatment of many diseases such as hypertension because herb has active ingredients which act as drug.

- Herbal drugs are less expensive than synthetic drugs and people in the rural area mostly used these drugs due to less side effects 23 .
- Herbal drugs also have different pharmacokinetic and pharmacodynamic properties which leads to therapeutic responses.

\subsection{Advantages of Herbal Medicines:}

I. Easily available.

II. Safe and effective.

III. Environmental friendly.

IV. Patient compliant.

V. Fewer side effects as compared to allopathic medicines. 24.

13.2. Herbal drugs which are used as antihypertensive agents:

\begin{tabular}{|c|c|c|c|}
\hline S.No. & $\begin{array}{l}\text { Drug (common } \\
\text { name) }\end{array}$ & Botanical Name & Pharmacological class \\
\hline 1. & Lotus & Nelumbo nucifera & Vasodilator ${ }^{25}$. \\
\hline 2. & Ginseng & Panex ginseng & Vasodilator 25. \\
\hline 3. & Garlic & Allium sativum & ACE inhibitors 25. \\
\hline 4. & Snake root & Rouwolfia serpentina & Vasodilator ${ }^{25 .}$ \\
\hline 5. & Ginger & Gingiber officinalis & Vasodilator 25. \\
\hline 6. & Ginko & Ginko biloba & Vasodilator 25. \\
\hline 7. & Hawthorn & Crataegus oxycantha & Vasodilator $^{25}$. \\
\hline 8. & Punarnava & Boerhavia diffusa & Diuretic 25. \\
\hline 9. & Ashwagandha & Withania somnifera & Diuretic $^{25}$. \\
\hline 10. & Arjuna & Termenalia arjuna & Diuretic ${ }^{25}$ \\
\hline 11. & Black cumin seeds & Nigella sativa & Centrally acting 25 . \\
\hline 12. & Alpinia & Alpinia zerumbet & Diuretic 25 \\
\hline 13. & Raisins & Vitis vinifera & Vasodilator ${ }^{25}$. \\
\hline 14. & Olive leaf & Olea europea & Vasodilator 25. \\
\hline 15. & Beetroot & Beta vulgaris & Nitrodilator 25 \\
\hline 16. & Tea & Camellia sinensis & Nitrodilator/diuretic ${ }^{26}$ \\
\hline 17. & Saffron & Crocus sativus & Calcium channel blocker ${ }^{26}$. \\
\hline 18. & Roselle & Hibiscus sabdariffa & Calcium channel blocker/vasodilator 26. \\
\hline 19. & King of bitter & Andrographis paniculata & Nitrodilar /ACE-inhibitor 26. \\
\hline 20. & Celery & Apium graveolens & Calcium channel blocker 26 . \\
\hline
\end{tabular}

\section{CONCLUSION}

The use of combination therapy as first line treatment will help more patients. This review is associated with treatment, management, adverse effects of drugs and diagnosis mainly.
There is need for safe and effective therapies to achieve recommended blood pressure targets. This review article also provides help in the detection of B.P. and in the selection of particular antihypertensive drug with herbal drugs. 


\section{REFERENCES}

1. Kishore J. Gupta N. Kohli C. Kumar N. Prevalence of hypertension and determination of its risk factors in rural Delhi. International journal of hypertension. 2016.

2. Bell K. Twiggs J. Bernie R. Hypertension: The Silent Killer: Updated JNC-8 Guideline. Harrison School of Pharmacy, Auburn University, Alabama Pharmacy Association. 2015.

3. Tain YL. Lin YJ. Sheen JM. Lin IC. Yu HR. Huang LT. Hsu CN Resveratrol prevents the combined maternal plus postweaning high-fat-diets-induced hypertension in male offspring. The Journal of nutritional biochemistry. 2017; 1(48):120-7.

4. Joseph P. Leong D. McKee M. Anand SS. Schwalm JD. Teo K. Mente A. Yusuf S. Reducing the global burden of cardiovascular disease, part 1: the epidemiology and risk factors. Circulation research. 2017; 121(6):677-94.

5. Brown D. Edwards H. Seaton L. Buckley T. Lewis's Medicalsurgical Nursing: Assessment and Management of Clinical Problems. Elsevier Health Sciences; 2017; 25.

6. Gredic M. Blanco I. Kovacs G. Helyes Z. Ferdinandy P. Olschewski H. Barberà JA. Weissmann N. Pulmonary hypertension in chronic obstructive pulmonary.

7. Izzo R. Patient with Essential Hypertension and Left Ventricular Enlargement. InHypertension and Cardiac Organ Damage 2017. 61-73.

8. Ripley TL. and Anna Barbato, Pharm. D., BCPS, AHSCP-CHC

9. Sudhakar R. George MK. Yasaswini B. Sundararajan . Mariyam AS Adverse drug reactions associated with anti-hypertensive drugs and its management. International Journal of Pharmaceutical Sciences and Research. 2016; 7(3):898.

10. O'Brien E. Asmar R. Beilin L. Imai Y.Mancia G. Mengden T. Myers M. Padfield P. Palatini P. Parati G. Pickering T. Practice guidelines of the European Society of Hypertension for clinic, ambulatory and self blood pressure measurement. Journal of hypertension. 2005; 23(4):697-701.

11. Verma S. Chan LL. Chee KS. Chen H. Chin SA. Chong SA. Chua W. Fones C. Fung D. Khoo CL. Kwek SK. Corrigendum. Ministry of health clinical practice guidelines: schizophrenia.

12. Bathgate CJ. Fernandez-Mendoza J.Insomnia, short sleep duration, and high blood pressure: recent evidence and future directions for the prevention and management of hypertension. Current hypertension reports. 2018; 20(6):52.

13. Siu AL. Screening for high blood pressure in adults: US Preventive Services Task Force recommendation statement Annals of internal medicine. 2015; 163(10):778-86.
14. National Institute for Health and Care Excellence. Hypertension in adults: diagnosis and management. CG 127.

15. Bialy LP. Wojcik C. Mlynarczuk-Bialy I. Mucosal delivery systems of antihypertensive drugs: A practical approach in general practice. Biomedical Papers. 2018; 162(2):71-8.

16. Sharma M. Sharma R. Jain DK. Nanotechnology based approaches for enhancing oral bioavailability of poorly water soluble antihypertensive drugs. Scientifica. 2016.

17. Sharma M. Sharma R. Jain DK. Nanotechnology based approaches for enhancing oral bioavailability of poorly water soluble antihypertensive drugs. Scientifica. 2016; 2016.

18. Deng Y. Zhang X. Shen H. He Q. Wu Z. Liao W. Yuan M. Application of the Nano-Drug Delivery System in Treatment of Cardiovascular Diseases. Frontiers in Bioengineering and Biotechnology. 2019; 7.

19. Khan AR. Liu M. Khan MW. Zhai G. Progress in brain targeting drug delivery system by nasal route. Journal of Controlled Release. 2017; 268:364-89.

20. Neeharika MS. Jyothi BJ. Chronotherapeutics: an optimizing approach to synchronize drug delivery with circadian rhythm. Journal of Critical Reviews. 2015; 2(4):31-40.

21. Alam T. Khan S. Gaba B. Haider MF. Baboota S. Ali J. Nanocarriers as treatment modalities for hypertension. Drug delivery. 2017; 24(1):358-69.

22. Lewis RS. Deen WM. Kinetics of the reaction of nitric oxide with oxygen in aqueous solutions. Chemical research in toxicology. 1994; 7(4):568-74.

23. Nisar B.Sultan A. Rubab SL. Comparison of medicinally important natural products versus synthetic drugs-a short commentary. Nat Prod Chem Res. 2017; 6(308):2.

24. Koka JA. Bhat MY. Wani AH. Allelopathic effect of leaf extracts of Punica granatum and Spiraea prunifolia against post-harvest rot of tomato and brinjal. Journal of Drug Delivery and Therapeutics. 2020; 10(2-s):1-6.

25. Agrawal M. Nandini D. Sharma V. Chauhan NS. Herbal remedies for treatment of hypertension. Int J Pharm Sci and Res. 2010; 1(5):1-21.

26. Chrysant SG. Chrysant GS. Herbs used for the treatment of hypertension and their mechanism of action. Current hypertension reports. 2017; 19(9):77. 